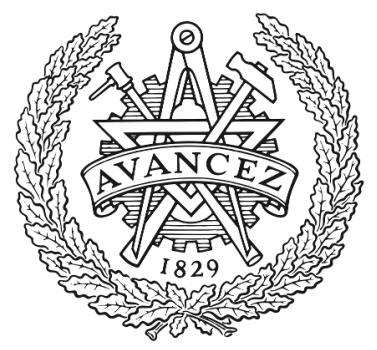

CHALMERS

UNIVERSITY OF TECHNOLOGY

\title{
Ammonia formation from nitric oxide over Pd-based catalysts in multicomponent feed gas compositions
}

Downloaded from: https://research.chalmers.se, 2023-04-26 15:37 UTC

Citation for the original published paper (version of record):

Adams, E., Skoglundh, M., Carlsson, P. (2017). Ammonia formation from nitric oxide over Pd-based catalysts in multicomponent feed gas

compositions. Catalysis Communications, 95: 26-30. http://dx.doi.org/10.1016/j.catcom.2017.03.001

N.B. When citing this work, cite the original published paper. 


\title{
Ammonia formation from nitric oxide over Pd-based catalysts in multicomponent feed gas compositions
}

\author{
Emma Catherine Adams*a, Magnus Skoglundh ${ }^{\mathrm{a}}$, Per-Anders Carlsson $^{\mathrm{a}}$ \\ ${ }^{a}$ Competence Centre for Catalysis, Chalmers University of Technology, SE-412 96 Göteborg, Sweden \\ *Corresponding author.Tel: +4631 772 2907, E-mail address: emma.adams@chalmers.se
}

\begin{abstract}
Using multicomponent gas feeds, the formation of ammonia from nitric oxide over $\mathrm{Pd} / \mathrm{Al}_{2} \mathrm{O}_{3}$ and $\mathrm{Pd} / \mathrm{Ce} / \mathrm{Al}_{2} \mathrm{O}_{3}$ model catalysts was compared to that of a commercially-available three-way catalyst. Steady-state oxygen-sweep experiments show that the highest activity for ammonia formation is obtained over the $\mathrm{Pd} / \mathrm{Ce} / \mathrm{Al}_{2} \mathrm{O}_{3}$ catalyst whilst the lowest activity is observed for the three-way catalyst. The latter is considered to be linked to the incorporation of rhodium, a component that promotes the $\mathrm{NO}_{x}$ reduction selectivity towards $\mathrm{N}_{2}$. Also, lean/rich cycling experiments were carried out to simulate the cycling conditions that passive-SCR aftertreatment systems depend upon. High activity is again seen over the $\mathrm{Pd} / \mathrm{Ce} / \mathrm{Al}_{2} \mathrm{O}_{3}$ catalyst during short periodic switches. For the three-way catalyst, longer periodic switches are required for the onset of ammonia formation due to the high oxygen storage capacity of this sample as compared to the other two. Hence, a future direction of investigation could be to develop materials with equivalent water-gas shift properties of ceria, but with reduced oxygen storage capacity so as to provide hydrogen for reaction without incurring a significant delay in ammonia formation.
\end{abstract}

Keywords: $\mathrm{NO}_{x}$ reduction, Passive-SCR, $\mathrm{NH}_{3}$ formation, Cycling experiments, Ceria promoter

\section{Introduction}

The fuel economy of gasoline fuelled vehicles can be improved by ensuring that the combustion takes place in the presence of excess oxygen, so-called lean operation [1]. Lean operation however, makes it challenging to reduce nitrogen oxides $\left(\mathrm{NO}_{x}\right)$ to $\mathrm{N}_{2}$, driving the development for new $\mathrm{NO}_{x}$ abatement concepts whereby the fuel economy can be improved whilst the tailpipe emissions are kept sufficiently low to fulfill future, and increasingly stringent, regulations $[2,3,4]$.

Passive-SCR is a newly emerging technique for $\mathrm{NO}_{x}$ abatement in both diesel and lean-burn spark ignition gasoline passenger vehicles. The concept of this technique is to generate an onboard supply of $\mathrm{NH}_{3}$ in the vehicle by utilizing the $\mathrm{NO}_{x}$ that is readily available in the exhaust stream. The formed $\mathrm{NH}_{3}$ can then be stored in an SCR catalyst placed downstream of the ammonia formation catalyst and used to reduce slipped $\mathrm{NO}_{x}$ when the engine operates under lean conditions. If sufficient amounts of $\mathrm{NH}_{3}$ can be produced during rich operation (low air-to-fuel ratio) and stored for complete reaction with $\mathrm{NO}_{x}$ to form $\mathrm{N}_{2}$ during the subsequent lean periods, an external urea injection system, as required by current $\mathrm{NH}_{3}-\mathrm{SCR}$ technology, may not be needed $[5,6,7]$.

We have previously identified $\mathrm{Pd} / \mathrm{Ce} / \mathrm{Al}_{2} \mathrm{O}_{3}$ as a promising catalyst formulation for ammonia formation in model gas compositions, i.e. $\mathrm{NO}+\mathrm{H}_{2}$ or $\mathrm{NO}+\mathrm{CO}+\mathrm{H}_{2} \mathrm{O}$ [8]. However, in order to identify this formulation as appropriate for real-life applications, it is also important to investigate the activity for $\mathrm{NH}_{3}$ formation in more complex feed compositions relevant to 
those one would encounter onboard a lean-burn gasoline vehicle. DiGuillio et al. have recently examined ammonia formation over a series of three-way catalysts (TWCs) for passiveSCR systems using gas mixtures containing $\mathrm{NO}, \mathrm{CO}, \mathrm{H}_{2}, \mathrm{C}_{3} \mathrm{H}_{6}$, $\mathrm{CO}_{2}$ and $\mathrm{H}_{2} \mathrm{O}$ [5]. In their systematic study, the authors identify through means of both steady-state and cycling experiments that the formation of $\mathrm{NH}_{3}$ is highly dependent on several factors, including the air-to-fuel ratio, temperature and catalyst formulation.

The objective of the present study is to add to the basic understanding of how components commonly included in threeway catalysts promote/inhibit ammonia formation when multicomponent feed gas compositions are used. This is approached by systematically comparing ammonia formation as a function of feed gas stoichiometry, as used by DiGuillio et al. [5], for model catalysts with reduced complexity, i.e. $\mathrm{Pd} / \mathrm{Al}_{2} \mathrm{O}_{3}$ and $\mathrm{Pd} / \mathrm{Ce} / \mathrm{Al}_{2} \mathrm{O}_{3}$, and a commercially available TWC.

\section{Experimental}

\subsection{Materials}

Three washcoated cordierite monolith substrates were investigated; (i) a commercially available three-way catalyst (TWC) containing $\mathrm{Pd}\left(28 \mathrm{~g} / \mathrm{ft}^{3}\right)$ and $\mathrm{Rh}\left(3 \mathrm{~g} / \mathrm{ft}^{3}\right)$ in addition to other materials such as cerium, zirconium and barium, (ii) a model $\mathrm{Pd} / \mathrm{Al}_{2} \mathrm{O}_{3}$ catalyst $\left(21 \mathrm{~g} / \mathrm{ft}^{3}\right)$ and (iii) a model $\mathrm{Pd} / \mathrm{Ce} / \mathrm{Al}_{2} \mathrm{O}_{3}$ catalyst $\left(12 \mathrm{~g} / \mathrm{ft}^{3}\right)$, prepared in-house via incipient wetness impregnation (method described in detail elsewhere [8]).

\subsection{Catalytic evaluation}

Catalytic activity measurements were conducted using a continuous flow reactor as described by Kannisto et al. [9]. In short, the system consists of a quartz tube surrounded with a heating coil and insulation. It contains two thermocouples to measure the temperature $10 \mathrm{~mm}$ before and in the centre of the monolith sample. Two uncoated (blank) cordierite monoliths were placed on either side of the sample monolith in the quartz tube to minimize temperature gradients in the sample by reducing axial radiation heat losses. With this arrangement, a nearly isothermal sample (temperature gradients below $1{ }^{\circ} \mathrm{C}$ ) is achieved when cooling/heating in Argon only [10]. The inlet gas composition was controlled using mass flow controllers (Bronkhorst Hi-Tech LOW- $\triangle \mathrm{P}$-FLOW) and the outlet gas composition was analysed using an FTIR gas-analyzer (MKS 2030 HS) with a gas sampling cell volume of $200 \mathrm{ml}$. With the total flow used here the response time for a step-change between two stationary levels is 20 - 23 seconds [11]. All experiments were carried out with an Ar balance in order to keep the total gas flow constant at $1000 \mathrm{ml} / \mathrm{min}$, corresponding to a gas hourly space velocity (GHSV) of $20,000 \mathrm{~h}^{-1}$. Prior to the activity measurements, the monolith samples were exposed to 2 vol.\% $\mathrm{O}_{2}$ at 500 ${ }^{\circ} \mathrm{C}$ for 30 minutes in order to remove preadsorbed carbonaceous species from the surface.

\subsubsection{Steady-state experiments}

Steady-state experiments were conducted in order to measure the formation of $\mathrm{NH}_{3}$ that could be achieved over each sample as a function of the stoichiometric-value (S-value) of the feed. The S-value characterizes the net oxidizing-reducing character of the inlet feed gas composition and is calculated according to the following equation [12]:

$$
\mathrm{S}=\frac{2\left[\mathrm{O}_{2}\right]+[\mathrm{NO}]}{[\mathrm{CO}]+\left[\mathrm{H}_{2}\right]+9\left[\mathrm{C}_{3} \mathrm{H}_{6}\right]}
$$

Calculated S-values less than 1 represent gas compositions which are net-reducing in character. When $S$ is equal to 1 , the fed stream is at the stoichiometric point, whilst feeds resulting in S-values above 1 are net-oxidizing. Feed gas compositions with constant concentrations of $\mathrm{NO}, \mathrm{CO}, \mathrm{H}_{2}, \mathrm{C}_{3} \mathrm{H}_{6}, \mathrm{CO}_{2}$ and $\mathrm{H}_{2}$ were fed whilst the concentration of $\mathrm{O}_{2}$ available at each 
Table 1: Feed gas compositions during steady-state and cycling measurements. The stoichiometric number $(\mathrm{S})$ is defined as $\left(2\left[\mathrm{O}_{2}\right]+[\mathrm{NO}]\right) /\left([\mathrm{CO}]+\left[\mathrm{H}_{2}\right]+9\left[\mathrm{C}_{3} \mathrm{H}_{6}\right]\right)$

\begin{tabular}{cccccccc}
\hline $\begin{array}{c}\text { Stoichiometric } \\
\text { number }(\mathrm{S})\end{array}$ & $\begin{array}{c}\mathrm{O}_{2} \\
(\%)\end{array}$ & $\begin{array}{c}\mathrm{NO} \\
(\%)\end{array}$ & $\begin{array}{c}\mathrm{CO} \\
(\%)\end{array}$ & $\begin{array}{c}\mathrm{H}_{2} \\
(\%)\end{array}$ & $\begin{array}{c}\mathrm{C}_{3} \mathrm{H}_{6} \\
(\%)\end{array}$ & $\begin{array}{c}\mathrm{CO}_{2} \\
(\%)\end{array}$ & $\begin{array}{c}\mathrm{H}_{2} \mathrm{O} \\
(\%)\end{array}$ \\
\hline- & 8.00 & 0.075 & - & - & - & 5.0 & 5.0 \\
1.009 & 1.590 & 0.15 & 1.8 & 0.60 & 0.10 & 5.0 & 5.0 \\
0.970 & 1.525 & 0.15 & 1.8 & 0.60 & 0.10 & 5.0 & 5.0 \\
0.961 & 1.510 & 0.15 & 1.8 & 0.60 & 0.10 & 5.0 & 5.0 \\
0.858 & 1.340 & 0.15 & 1.8 & 0.60 & 0.10 & 5.0 & 5.0 \\
0.688 & 1.060 & 0.15 & 1.8 & 0.60 & 0.10 & 5.0 & 5.0 \\
0.529 & 0.790 & 0.15 & 1.8 & 0.60 & 0.10 & 5.0 & 5.0 \\
\hline
\end{tabular}

S-value was changed, as shown in Table 1. All experimental protocols were carried out at an inlet temperature of $500{ }^{\circ} \mathrm{C}$.

\subsubsection{Cycling experiments}

As passive-SCR is a technology that depends on dynamic switching between rich and lean engine operation, it is of vital importance to determine how the catalysts perform under transient conditions. The feed gas composition was therefore altered between a large excess of oxygen $(8$ vol.\%) and $\mathrm{S}=$ 0.688 for eight cycles in order for a reproducible response to be achieved for each sample. The S-value of the lean conditions could not be calculated according to equation 1 due to the absence of reducing species in the feed. Two cycling periods (long and short) were investigated. During the long periods, the feed was kept at $S=0.688$ for 60 seconds, before switching to the feed containing 8 vol. $\% \mathrm{O}_{2}$ for 120 seconds. For the short periods, the corresponding time was 20 and 40 seconds respectively.

\subsubsection{Oxygen storage experiments}

The dynamic oxygen storage capacity (OSC) at $500{ }^{\circ} \mathrm{C}$ of each sample was determined using a reactor setup similar to that described above. However, the total flow used was $300 \mathrm{ml} / \mathrm{min}$ and solenoid valves were used to allow rapid exchange of gases. A more detailed description of the reactor setup has been reported elsewhere [13]. The samples were pretreated at $500{ }^{\circ} \mathrm{C}$ in a flow of $\mathrm{O}_{2}$ in order to remove any pre-adsorbed carbonaceous species and subsequently reduced by flowing $\mathrm{CO}$. The sample was then exposed to alternate 30 second pulses of either 2 vol. $\% \mathrm{O}_{2}$ or 4 vol. $\% \mathrm{CO}$, with a 60 second interval containing Ar only between each pulse in order for weakly-bound oxygen to desorb from the catalyst surface. This cycle was repeated seven times so that reproducible responses were obtained. The dynamic OSC was then quantified in terms of micromoles of $\mathrm{CO}_{2}$ produced per sample (washcoat + cordierite substrate).

\section{Results and Discussion}

Figure 1 shows the steady-state formation of ammonia at 500 ${ }^{\circ} \mathrm{C}$ over the samples as a function of the S-value of the feed gas composition. For all samples, the highest amount of $\mathrm{NH}_{3}$ is formed at the lowest $\mathrm{S}$-value, 0.529. The $\mathrm{NH}_{3}$ formation then decreases as the feed becomes increasingly oxidizing. For the highest $\mathrm{S}$-value investigated, $\mathrm{S}=1.009$, no formation of $\mathrm{NH}_{3}$ is detected for any of the investigated samples. When $\mathrm{S}<1$, the highest concentrations of $\mathrm{NH}_{3}$ are formed over the $\mathrm{Pd} / \mathrm{Ce} / \mathrm{Al}_{2} \mathrm{O}_{3}$ sample, whilst the lowest concentrations are formed over the TWC. The formation of $\mathrm{NH}_{3}$ from $\mathrm{NO}$ and $\mathrm{H}_{2}$ over noble metals has been well documented since the early development of the TWC in the 1970s $[14,15,16]$. The reaction involves dissociative adsorption of $\mathrm{NO}$ on noble metal sites, platinum and palladium based catalysts are reported as having exceptionally high activity [14]. The higher activity for $\mathrm{NH}_{3}$ formation over $\mathrm{Pd}$ compared to $\mathrm{Pt}$ with regards to temperature range and presence of $\mathrm{CO}$ has also been recognised [4]. In the presence of $\mathrm{CO}$, surface-bound isocyanate groups can be 
formed from $\mathrm{CO}$ and dissociated NO before being hydrolysed to form ammonia $[17,18]$. Although palladium has been identified as the active site for ammonia formation via both reaction routes, i.e. the direct reaction of NO with hydrogen and the hydrolysis of isocyanates, the most active catalyst in the present study, $\mathrm{Pd} / \mathrm{Ce} / \mathrm{Al}_{2} \mathrm{O}_{3}$, was the sample which contained the least amount of Pd. This suggests that other factors in the preparation of the washcoats significantly impacts the catalytic activity of the samples, i.e. noble metal dispersion and support grain size, support materials composition etc. Upon consideration of the differences in catalyst formulation, certain speculations can be made regarding the differences in behaviour and how specific components may be beneficial or detrimental for passive-SCR applications.

As the activity study was conducted at $500{ }^{\circ} \mathrm{C}$, it is likely that both water-gas shift and steam reforming reactions are able to provide hydrogen for ammonia formation during the netreducing reaction conditions for $S<1$ [19]. The occurence of these reactions is most likely the explanation for the difference in activity between $\mathrm{Pd} / \mathrm{Al}_{2} \mathrm{O}_{3}$ and $\mathrm{Pd} / \mathrm{Ce} / \mathrm{Al}_{2} \mathrm{O}_{3}$. Indeed, Mejía-Centeno et al. have previously reported that the addition of 10 wt.\% Ce to $\mathrm{Pd} / \mathrm{Al}_{2} \mathrm{O}_{3}$ enhances the comparative generation of $\mathrm{H}_{2}$ for feed gas compositions containing $\mathrm{NO}, \mathrm{CO}, \mathrm{H}_{2}$, $\mathrm{C}_{3} \mathrm{H}_{8}$ and $\mathrm{O}_{2}$ [20]. As the TWC also contains Ce, one may expect that the activity for $\mathrm{NH}_{3}$ formation over this sample should also exceed that of $\mathrm{Pd} / \mathrm{Al}_{2} \mathrm{O}_{3}$. However, the presence of $\mathrm{Rh}$ in the washcoat of the TWC is most likely the reason for the high selectivity to $\mathrm{N}_{2}$ observed over the sample during the course of $\mathrm{NO}_{x}$ reduction. $\mathrm{Rh}$ has been extensively studied since the introduction of the TWC and is known to promote N-pairing of adsorbed NO molecules prior to the breakage of the N-O bond [21], hence suppressing the formation of $\mathrm{NH}_{3}$.

The slip and formation of $\mathrm{NO}, \mathrm{CO}$ and $\mathrm{N}_{2} \mathrm{O}$ during the steady-state experiments are displayed in Figure 2. As no

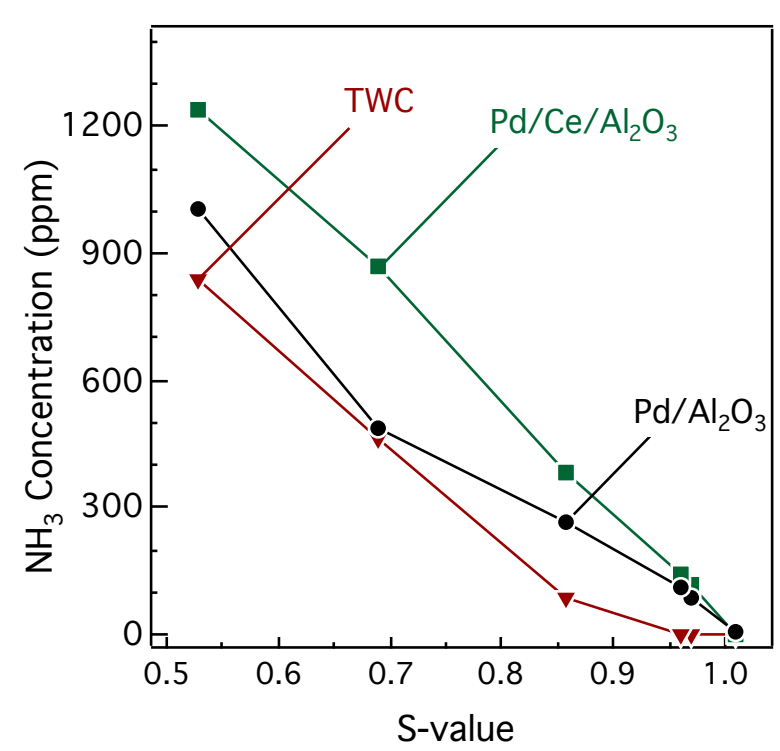

Figure 1: Steady-state formation of $\mathrm{NH}_{3}$ over $\mathrm{Pd} / \mathrm{Al}_{2} \mathrm{O}_{3}, \mathrm{Pd} / \mathrm{Ce} / \mathrm{Al}_{2} \mathrm{O}_{3}$ and TWC as a function of the $\mathrm{S}$-value of the feed gas composition at an inlet temperature of $500{ }^{\circ} \mathrm{C}$. GHSV $=20,000 \mathrm{~h}^{-1}$, Ar balance employed.

propene was observed in the reactor outlet, it is likely that the $\mathrm{CO}$ that is detected during the experiment is not a result of $\mathrm{CO}$ slip alone, but can be ascribed to partial oxidation or steam reforming of propene. Indeed, this observation corroborates the trend of increasing outlet CO concentration coupled with increasing activity for $\mathrm{NH}_{3}$ formation that has been reported in other passive-SCR studies [5, 22]. The substantial formation of $\mathrm{CO}$ as the $\mathrm{NH}_{3}$ formation increases over the samples is undoubtedly a major concern for passive-SCR applications. Negligible amounts of $\mathrm{NO}$ and $\mathrm{N}_{2} \mathrm{O}$ are formed over the samples when exposed to feed gas compositions of $\mathrm{S}<1$ and no $\mathrm{NO}_{2}$ is detected at any S-value. For the concentration of inlet and outlet nitrogen species to be balanced, it is therefore assumed that $\mathrm{N}_{2}$ is the only other product formed over the catalysts when $\mathrm{S}$ $<1$.

As passive-SCR is a technique that is dependent upon transient switching between rich and lean operation, it is relevant to compare the activity of ammonia formation for the three samples during cycling between net-oxidizing and net-reducing environments. In this experiment, the concentration of NO fed 


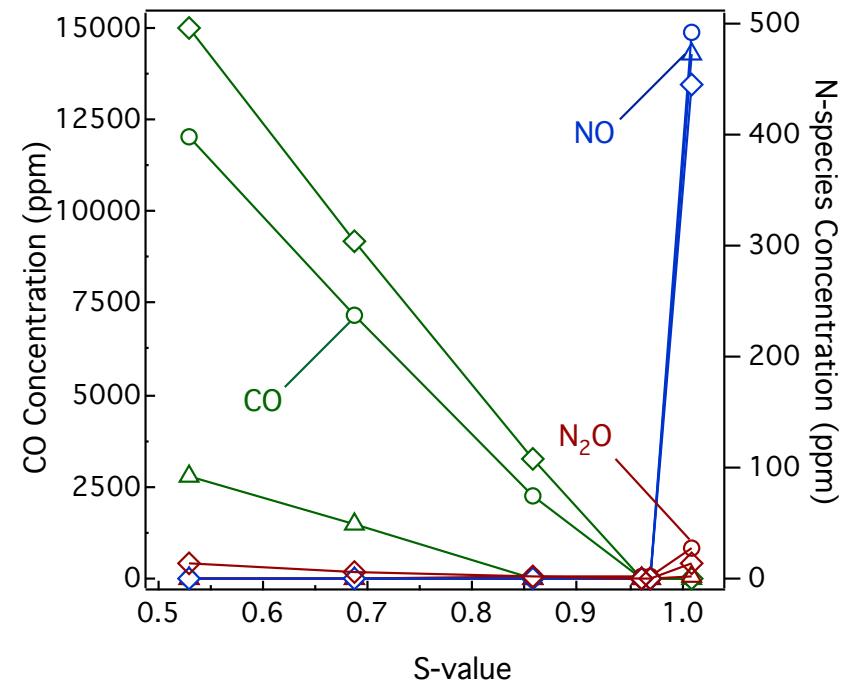

Figure 2: Outlet concentrations of $\mathrm{CO}, \mathrm{NO}$ and $\mathrm{N}_{2} \mathrm{O}$ measured over $\mathrm{Pd} / \mathrm{Al}_{2} \mathrm{O}_{3}$ $(\diamond), \mathrm{Pd} / \mathrm{Ce} / \mathrm{Al}_{2} \mathrm{O}_{3}(\circ)$ and TWC $(\triangle)$ as a function of the $\mathrm{S}$-value of the feed gas composition at an inlet temperature of $500{ }^{\circ} \mathrm{C}$. GHSV $=20,000 \mathrm{~h}^{-1}$, Ar balance employed.

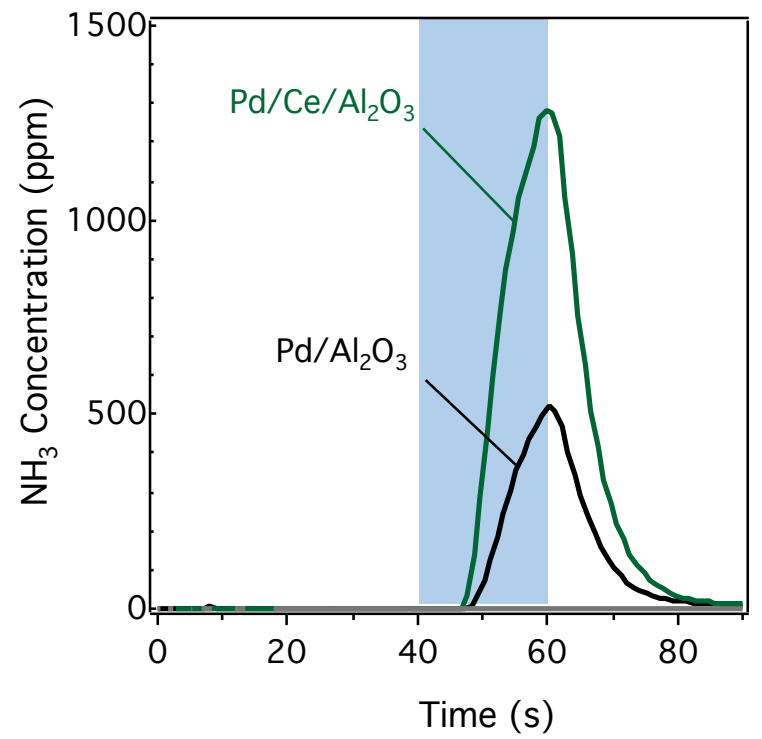

Figure 3: Transient formation of $\mathrm{NH}_{3}$ over $\mathrm{Pd} / \mathrm{Al}_{2} \mathrm{O}_{3}$ and $\mathrm{Pd} / \mathrm{Ce} / \mathrm{Al}_{2} \mathrm{O}_{3}$ during cycling between rich $(\mathrm{S}=0.688)$ and lean $\left(8\right.$ vol. $\left.\% \mathrm{O}_{2}\right)$ feed compositions for 20 and 40 seconds respectively. $\mathrm{No} \mathrm{NH}_{3}$ was detected over the TWC. Shaded panels indicate areas of rich operation. GHSV $=20,000 \mathrm{~h}^{-1}$, balance Ar employed and temperature was $500{ }^{\circ} \mathrm{C}$.

to the reactor during the rich periods was twice that of the NO concentration fed during the lean periods. As the stoichiometry between $\mathrm{NO}$ and $\mathrm{NH}_{3}$ in the SCR reaction ideally is $1: 1$, the length of the lean periods were twice that of the rich. This timing assumes complete and instantaneous conversion of NO to $\mathrm{NH}_{3}$ over the samples during the net-reducing feed compo- sition. Figure 3 shows the transient formation of $\mathrm{NH}_{3}$ over the samples during short-length periods between rich and lean reaction environments (20 and $40 \mathrm{~s}$ respectively). For reducing feeds, $\mathrm{NH}_{3}$ formation is observed over the $\mathrm{Pd} / \mathrm{Al}_{2} \mathrm{O}_{3}$ and $\mathrm{Pd} / \mathrm{Ce} / \mathrm{Al}_{2} \mathrm{O}_{3}$ samples only. The delay before $\mathrm{NH}_{3}$ formation is observed is approximately the same $(5 \mathrm{~s})$, but a considerably higher amount of $\mathrm{NH}_{3}$ is formed over the sample containing cerium. For the TWC, no $\mathrm{NH}_{3}$ formation is observed. Although the reducibility of ceria (most noteably ceria combined with zirconia) is utilised in conventional three-way catalysts, the storage of oxygen is deemed as a negative characteristic for materials to be utilised for passive-SCR applications [22, 23, 5]. One of the main reasons to include ceria as a component of the three-way catalyst is that ceria is able to act as an oxygen buffer, ensuring that fluctuations in air-to-fuel ratios are compensated for [24]. In passive-SCR systems however, it is necessary for oxygen to be removed from the catalyst surface so that hydrogen is not consumed via the formation of water before ammonia formation can take place [22]. The period required for excess surface oxygen to be removed from the washcoat can therefore result in a significant delay in ammonia formation if the oxygen storage capacity of the employed catalyst is high. The TWC washcoat used in the present study was determined to have an order of magnitude higher dynamic OSC (370 $\mu \mathrm{mol})$ upon comparison with $\mathrm{Pd} / \mathrm{Ce} / \mathrm{Al}_{2} \mathrm{O}_{3}(40 \mu \mathrm{mol})$ and even higher compared to $\mathrm{Pd} / \mathrm{Al}_{2} \mathrm{O}_{3}(8.8 \mu \mathrm{mol})$. It should be noted that the reported OSC of the samples has not been standardized; the amount of oxygen adsorbed on each monolith sample is expressed rather than the amount of oxygen adsorbed per gram of washcoat. This is because, although the mass of $\mathrm{Pd} / \mathrm{Al}_{2} \mathrm{O}_{3}$ and $\mathrm{Pd} / \mathrm{Ce} / \mathrm{Al}_{2} \mathrm{O}_{3}$ coated onto the monoliths is known to be the same $(200 \mathrm{mg})$, the total mass of the TWC material coated on the monolith provided in this study is not reported.

As no $\mathrm{NH}_{3}$ formation is observed over the TWC during short- 
length pulses, the experiment was repeated with a longer duration of lean and rich periods whilst maintaining the $2: 1$ ratio between oxidizing and reducing conditions by employing timings of 120 and 60 s respectively. The results are displayed in Figure 4. It can be seen that the required time before $\mathrm{NH}_{3}$ formation is observed over the TWC is approximately $30 \mathrm{~s}$, a period that is substantially longer than for the $\mathrm{Pd} / \mathrm{Al}_{2} \mathrm{O}_{3}$ and $\mathrm{Pd} / \mathrm{Ce} / \mathrm{Al}_{2} \mathrm{O}_{3}$ samples and would result in a significant fuel penalty. Although the inclusion of ceria within the washcoat formulation is beneficial for the provision of hydrogen for ammonia formation, the combination of ceria with zirconia may result in too high oxygen storage capacity for this application [25, 26]. Traditionally, zirconia is necessary in order to thermally stabilise the ceria component of the conventional TWC [27, 28]. Future areas of investigation may therefore be (i) to determine whether ceria can be made more thermally durable without incurring a significant increase in OSC or (ii) lowering the amount of oxygen storage components, i.e. ceria, in the washcoat by identifying alternative materials, with equivalent WGS activity to ceria, which could be used for the provision of hydrogen instead.

Figure 5 shows the slip and formation of $\mathrm{NO}, \mathrm{NO}_{2}$ and $\mathrm{CO}$ during the cycling experiments. For oxidizing feed gas compositions, significant $\mathrm{NO}$ slip and $\mathrm{NO}_{2}$ formation is observed over all samples. The formation of $\mathrm{NO}_{2}$ in the presence of excess $\mathrm{O}_{2}$ indicates that, whilst NO adsorption is still feasible on oxidized Pd sites, the ability for NO to dissociate is hindered $[29,30]$. Thus, the release of weakly bound NO and the reaction of NO with adsorbed $\mathrm{O}$ atoms becomes more likely. Release of $\mathrm{NO}_{x}$ is observed from all samples upon switching from lean to rich reaction environment, indicating $\mathrm{NO}_{x}$ storage taking place during the lean phase. The most significant release of NO however, is observed for the TWC. This is due to the presence of $\mathrm{Ba}$ within the washcoat, a compound typically associated with and extensively studied as a storage component in $\mathrm{NO}_{x}$

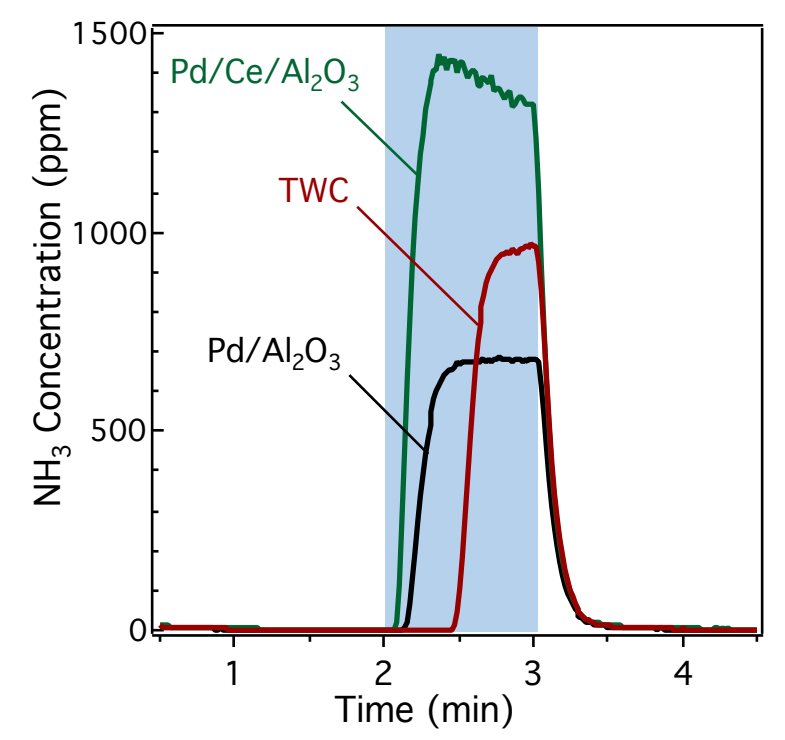

Figure 4: Transient formation of $\mathrm{NH}_{3}$ over $\mathrm{Pd} / \mathrm{Al}_{2} \mathrm{O}_{3}, \mathrm{Pd} / \mathrm{Ce} / \mathrm{Al}_{2} \mathrm{O}_{3}$ and the TWC during cycling between rich $(\mathrm{S}=0.688)$ and lean $\left(8\right.$ vol. $\left.\% \mathrm{O}_{2}\right)$ feed compositions for 60 and 120 seconds respectively. Shaded panels indicate areas of rich operation. GHSV $=20,000 \mathrm{~h}^{-1}$, balance Ar employed and temperature was $500{ }^{\circ} \mathrm{C}$.

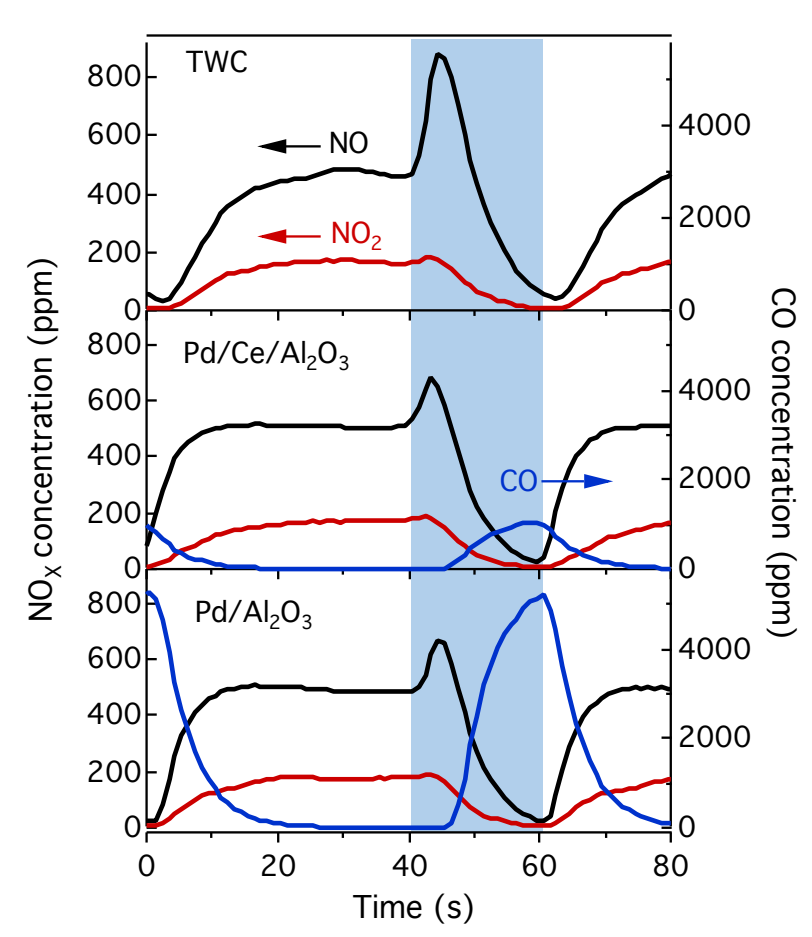

Figure 5: Transient formation/slip of $\mathrm{NO}, \mathrm{NO}_{2}$ and $\mathrm{CO}$ over $\mathrm{Pd} / \mathrm{Al}_{2} \mathrm{O}_{3}$, $\mathrm{Pd} / \mathrm{Ce} / \mathrm{Al}_{2} \mathrm{O}_{3}$ and the TWC during cycling between rich $(\mathrm{S}=0.688)$ and lean $\left(8\right.$ vol. $\left.\% \mathrm{O}_{2}\right)$ feed compositions for 20 and 40 seconds respectively. Shaded panels indicated periods of rich operation. GHSV $=20,000 \mathrm{~h}^{-1}$, balance $\mathrm{Ar}$ employed and temperature was $500{ }^{\circ} \mathrm{C}$.

storage and reduction catalysts [31]. Several reactions are involved during the $\mathrm{NO}_{x}$ storage process in the presence of 
excess oxygen. Fundamentally, NO reacts over the noble metal phase to form $\mathrm{NO}_{2}$ before coming into contact with nearby $\mathrm{Ba}$ sites $[32,3]$. This close-proximity between noble metal and $\mathrm{Ba}$ results in the formation of relatively stable $\mathrm{Ba}\left(\mathrm{NO}_{3}\right)_{2}$ species $[33,34]$. In line with the results we report, Castoldi et al. have compared the $\mathrm{NO}_{x}$ storage of $\mathrm{Pt} / \mathrm{Al}_{2} \mathrm{O}_{3}$ with and without the presence of $\mathrm{Ba}$ and confirmed that, whilst still possible, the absence of Ba within the washcoat results in significantly lower concentrations of more weakly bound $\mathrm{NO}_{x}$ being adsorbed. It is likely that, in addition to stored oxygen removal, the removal of stored $\mathrm{NO}_{x}$ from the catalyst surface by hydrocarbons, $\mathrm{CO}$ and/or $\mathrm{H}_{2}$ is also required prior to ammonia formation during rich cycles. Thus, the presence of $\mathrm{Ba}$ and other $\mathrm{NO}_{x}$ storage components in the washcoat may also contribute to delayed formation of $\mathrm{NH}_{3}$ upon switching from lean to rich operation. Indeed, this trend was seen by Lindholm et al. [35] whilst investigating $\mathrm{NO}_{x}$ reduction with $\mathrm{H}_{2}$ over $\mathrm{Pt} / \mathrm{Ba} / \mathrm{Al}_{2} \mathrm{O}_{3}$ during lean/rich cycling. They report that, when switching to rich operation, stored $\mathrm{NO}_{x}$ is first released from the surface and thereafter reduced to $\mathrm{N}_{2} \mathrm{O}$ before $\mathrm{NH}_{3}$ breakthrough is observed, a sequence of product formation which is also confirmed by Pihl et al. [36]

In the present study, $\mathrm{CO}$ breakthrough is detected during rich operation over $\mathrm{Pd} / \mathrm{Al}_{2} \mathrm{O}_{3}$ and $\mathrm{Pd} / \mathrm{Ce} / \mathrm{Al}_{2} \mathrm{O}_{3}$, with the time of onset coinciding with the onset for $\mathrm{NH}_{3}$ formation. As neither $\mathrm{CO}$ nor $\mathrm{NH}_{3}$ is detected over the TWC during short-term rich pulses, the case for the formation of these two species being related strengthens. The reaction of inlet propene with steam to form $\mathrm{CO}$ and the supply of $\mathrm{H}_{2}$ required for reaction with adsorbed $\mathrm{NO}$ for $\mathrm{NH}_{3}$ formation is therefore proposed as the reason for the coupling of these two products. Hydrocarbons of various chain lengths and functional groups are present in the exhaust stream of gasoline vehicles. This will likely have an effect on both the amount of hydrogen which can be provided for ammonia formation, in addition to the amount of CO emitted from the vehicle.

\section{Conclusions}

This study shows that, whilst ammonia can be formed from nitric oxide over a TWC, this catalyst formulation contains several components that severely inhibit and/or delay ammonia formation under lean/rich cycling of a multicomponent gas feed. The inclusion of rhodium increases selectivity to $\mathrm{N}_{2}$. Moreover, the storage components for oxygen (ceria) and, in this case, also $\mathrm{NO}_{x}$ (baria) need to be emptied/regenerated to allow ammonia to be formed. However, analysis of the activity for $\mathrm{NH}_{3}$ formation over the $\mathrm{Pd} / \mathrm{Ce} / \mathrm{Al}_{2} \mathrm{O}_{3}$ model catalyst shows that the use of ceria as an efficient WGS component, especially when promoted with noble metals (in this case Pd), is beneficial for the improved activity towards ammonia formation due to the provision of hydrogen. Hence, a future direction of investigation could be to develop materials with equivalent catalytic properties of ceria but with reduced oxygen storage capacity.

\section{Acknowledgments}

This work was financially supported by the Swedish Energy Administration through the FFI program and the Competence Centre for Catalysis (KCK), which is financially supported by Chalmers University of Technology, the Swedish Energy Agency and the member companies: AB Volvo, ECAPS AB, Haldor Topsøe A/S, Volvo Car Corporation AB, Scania CV $\mathrm{AB}$, and Wärtsilä Finland $\mathrm{Oy}$.

\section{References}

[1] Y. Liu, M. P. Harold, and D. Luss Appl. Catal. B: Environ., vol. 121, pp. 239-251, 2012. 
[2] S. M. Park, M.-Y. Kim, E. S. Kim, H.-S. Han, and G. Seo Appl. Catal. A: Gen., vol. 395, pp. 120-128, 2011.

[3] A. Lindholm, N. Currier, J. Li, A. Yezerets, and L. Olsson J. Catal., vol. 258, pp. 273-288, 2008.

[4] N. Macleod and R. M. Lambert Appl. Catal. B: Environ., vol. 46, pp. 483495, 2003.

[5] C. D. DiGiulio, J. A. Pihl, J. E. Parks II, M. D. Amiridis, and T. J. Toops Catal. Today, vol. 231, pp. 33-45, 2014.

[6] V. Y. Prikhodko, J. E. Parks, J. A. Pihl, and T. J. Toops SAE Int. J. Engines, vol. 7, pp. 1235-1243, 2014.

[7] S. H. Oh and T. Triplett Catal. Today, vol. 231, pp. 22-32, 2014.

[8] E. C. Adams, M. Skoglundh, P. Gabrielsson, M. Laurell, and P.-A. Carlsson Catal. Today, vol. 59, pp. 210-216, 2016.

[9] H. Kannisto, X. Karatzas, J. Edvardsson, L. J. Pettersson, and H. H. Ingelston Appl. Catal. B: Environ., vol. 104, pp. 74-83, 2011.

[10] C. Wang-Hansen, C. J. Kamp, M. Skoglundh, B. Andersson, and P.-A. Carlsson J. Phys. Chem. C, vol. 115, pp. 16098-16108, 2011.

[11] S. Soheil, C. Wang-Hensen, R. Andersson, and B. Andersson Can. J. Chem. Eng., vol. 92, pp. 1570-1578, 2014.

[12] J. C. Summers and K. Baron J. Catal., vol. 57, pp. 380-389, 1979.

[13] L. Kylhammer, P.-A. Carlsson, and M. Skoglundh J. Catal., vol. 284, pp. 50-59, 2011.

[14] M. Shelef and H. S. Gandhi Ind. Eng. Chem. Prod. Res. Develop., vol. 11, pp. 393-396, 1972.

[15] H. G. Stenger and J. S. Hepburn Energy \& Fuels, vol. 1, pp. 412-416, 1987.

[16] T. P. Kobylinski and B. W. Taylor J. Catal., vol. 33, pp. 376-384, 1974.

[17] M. L. Unland Science, vol. 179, pp. 567-569, 1973.

[18] M. L. Unland J. Catal, vol. 31, pp. 459-465, 1973.

[19] N. V. Heeb, C. J. Saxer, A.-M. Forss, and S. Bruhlmann Atmos. Environ., vol. 42, pp. 2543-2554, 2008.

[20] I. Mejía-Centeno, S. Castillo, and G. A. Fuentes Appl. Catal. B: Environ., vol. 119, pp. 234-240, 2012.

[21] M. Shelef and G. W. Graham Catal. Rev. Sci. Eng., vol. 36, pp. 433-457, 1994.

[22] J. Theis, J. Kim, and G. Cavataio SAE Int. J. Fuels Lubr., vol. 8, 2006.

[23] V. Y. Prikhodko, J. E. Parks, J. A. Pihl, and T. J. Toops Catal. Today, vol. 267, pp. 202-209, 2016.

[24] H. S. Gandhi, G. W. Graham, and R. W. McCabe J. Catal., vol. 216, pp. 433-442, 2003.

[25] M. H. Yao, R. J. Baird, F. W. Kunz, and T. E. Hoost J. Catal., vol. 166, pp. 67-74, 1997.

[26] Z. Q. Han, J. Q. Wang, H. J. Yan, M. Q. Shen, W. L. Wang, M. Wang, and
M. Yang Catal. Today, vol. 158, pp. 481-489, 2010.

[27] B. Yue, R. Zhou, X. Zheng, and W. Lu Mater. Chem. Phys., vol. 114, pp. 722-727, 2009.

[28] M. Pijolat, M. Prin, M. Soustelle, and P. Touret, O an Nortier J. Chem. Soc. Faraday trans., vol. 91, pp. 3941-3948, 1995.

[29] F. Klingstedt, A. K. Neyestanaki, R. Byggningsbacka, L.-E. Lindfors, M. Lunden, M. Petersson, P. Tengstrom, T. Ollonqvist, and Vayrynen Appl. Catal. A: Gen, vol. 209, pp. 301-316, 2001.

[30] S. Moriki, Y. Inoue, E. Miyazaki, and I. Yasumori J. Chem. Soc., Faraday Trans. 1, vol. 78, pp. 171-183, 1982.

[31] E. Fridell, M. Skoglundh, B. Westerberg, S. Johansson, and G. Smedler J. Catal., vol. 183, pp. 196-209, 1999.

[32] J. F. Mahzoul, H aand Brilhac and P. Gilot Appl. Catal. B: Environ., vol. 20, pp. 47-55, 1999.

[33] V. Medhekar, V. Balakotaiah, and M. P. Harold Catal. Today, vol. 121, pp. 226-236, 2007.

[34] I. Nova, L. Lietti, L. Castoldi, E. Tronconi, and P. Forzatti J. Catal., vol. 239, pp. 244-254, 2006.

[35] A. Lindholm, N. Currier, E. Fridell, A. Yezerets, and L. Olsson Appl. Catal. B: Environ., vol. 75, pp. 78-87, 2007.

[36] J. A. Pihl, J. E. Parks, C. S. Daw, and T. W. Root SAE Tech. Paper, vol. 2006-01-3441, 2006. 